\title{
Role of tumor necrosis factor superfamily in neuroinflammation and autoimmunity
}

\author{
Sandip Sonar and Girdhari Lal ${ }^{*}$ \\ National Centre for Cell Science, Pune, India
}

Tumor necrosis factor superfamily (TNFSF) molecules play an important role in the activation, proliferation, differentiation, and migration of immune cells into the central nervous system (CNS). Several TNF superfamily molecules are known to control alloimmunity, autoimmunity, and immunity. Development of transgenic and gene knockout animals, and monoclonal antibodies against TNFSF molecules have increased our understanding of individual receptor-ligand interactions, and their intracellular signaling during homeostasis and neuroinflammation. A strong clinical association has been observed between TNFSF members and CNS autoimmunity such as multiple sclerosis and also in its animal model experimental autoimmune encephalomyelitis. Therefore, they are promising targets for

OPEN ACCESS

Edited by:

Wolfgang Weninger,

Centenary Institute, Australia

Reviewed by:

Irun R. Cohen,

Weizmann Institute of Science, Israel

Amanda Katherine Huber,

University of Michigan, USA

*Correspondence: Girdhari Lal,

National Centre for Cell Science, NCCS Complex, Ganeshkhind, Pune, Maharashtra 411007, India glal@nccs.res.in

Specialty section: This article was submitted to Multiple Sclerosis and Neuroimmunology, a section of the journal Frontiers in Immunology

Received: 31 March 2015 Accepted: 05 July 2015

Published: 20 July 2015

Citation:

Sonar S and Lal G (2015) Role of tumor necrosis factor superfamily in neuroinflammation and autoimmunity. Front. Immunol. 6:364.

doi: 10.3389/fimmu.2015.00364 alternative therapeutic options to control autoimmunity. Although, TNFSF ligands are widely distributed and have diverse functions, we have restricted the discussions in this review to TNFSF receptor-ligand interactions and their role in the pathogenesis of neuroinflammation and CNS autoimmunity.

Keywords: autoimmunity, blood-brain barrier, multiple sclerosis, tumor necrosis factor, neuroinflammation

\section{Introduction}

$\mathrm{CD} 4^{+} \mathrm{T}$ cells are one of the key adaptive immune cells that play an important role in several autoimmune diseases like multiple sclerosis (MS), experimental autoimmune encephalomyelitis (EAE), inflammatory bowel disease (IBD), and collagen-induced arthritis (CIA). Interactions between tumor necrosis factor superfamily (TNFSF) ligands and TNF receptor superfamily (TNFRSF) receptors provide the costimulatory signals that control the survival, proliferation, differentiation, and effector function of immune cells. Therefore, signaling from these ligand-receptor pairs effectively

\footnotetext{
Abbreviations: APC, antigen-presenting cells; APRIL, a proliferation-inducing ligand; BAFF, B-cell activating factor; BBB, blood-brain barrier; BCMA, B-cell maturation factor; CNS, central nervous system; CTLA-4, cytotoxic T-lymphocyteassociated protein-4; DR, death domain containing receptor; EAE, experimental autoimmune encephalomyelitis; GA, glatiramer acetate; GITR, glucocorticoid-induced TNFR family-related gene; GITRL, glucocorticoid-induced TNFR familyrelated gene ligand; gld, generalized lymphoproliferative disease; GM-CSF, granulocyte-macrophage colony-stimulating factor; HEVM, herpes virus entry mediator; ICAM-1, intercellular adhesion molecule-1; LIGHT, homologous to lymphotoxins, exhibits inducible expression, and competes with HSV glycoprotein D for herpesvirus entry mediator (HVEM), a receptor expressed by T lymphocytes; lpr, lymphoproliferative; LT $\alpha$, lymphotoxin alpha; LT $\beta R$, lymphotoxin receptor beta; MMP, matrix metallopeptidase; MOG, myelin oligodendrocyte glycoprotein; MS, multiple sclerosis; RANK, receptor activator of NF- $\kappa B$; RANKL, receptor activator of NF- $\kappa B$ ligand; TACE, TNF alpha converting enzyme; TACI, transmembrane activator, calcium modulator, and cyclophilin ligand interactor; TNF, tumor necrosis factor; TNFR, TNF receptor; TNFRSF, TNF receptor superfamily; TNFSF, TNF superfamily; TRAF, TNF receptor-associated factor; TRAIL, TNF-related apoptosisinducing ligand; TRAILR, TNF-related apoptosis-inducing ligand receptor; Treg, regulatory CD4 T cells; TWEAK, TNF-related weak inducer of apoptosis; VCAM-1, vascular cell adhesion molecule-1; VEGI, vascular endothelial cell-growth inhibitor.
} 
helps in maintaining immune cell homeostasis and in regulating the pathology of autoimmune diseases (1-4).

About 19 TNFSF ligands have been identified, which include TNF- $\alpha$, TNF- $\beta$ [also known as lymphotoxin alpha (LT $\alpha)$ ], lymphotoxin- $\beta$ (LT- $\beta$ ), CD27L, CD30L, CD40L, FasL, 4-1BBL, OX40L, TNF-related apoptosis-inducing ligand (TRAIL), LIGHT (homologous to lymphotoxins, exhibits inducible expression, and competes with HSV glycoprotein D for herpesvirus entry mediator (HVEM), a receptor expressed by $\mathrm{T}$ lymphocytes), receptor activator of NF- $\kappa \mathrm{B}$ ligand (RANKL), TNF-related weak inducer of apoptosis (TWEAK), a proliferation-inducing ligand (APRIL), B-cell activating factor (BAFF), vascular endothelial cell-growth inhibitor (VEGI), ectodysplasin A (EDA-A1, EDAA2), and glucocorticoid-induced TNFR family-related gene ligand (GITRL) (Figure 1). While expressions of TNFSF ligands are induced largely on professional antigen-presenting cells (APCs; dendritic cells, B cells, macrophages), their expression is also reported on T cells, NK cells, mast cells, eosinophils, basophils, endothelial cells, thymic epithelial cells, and smooth muscle cells (5).

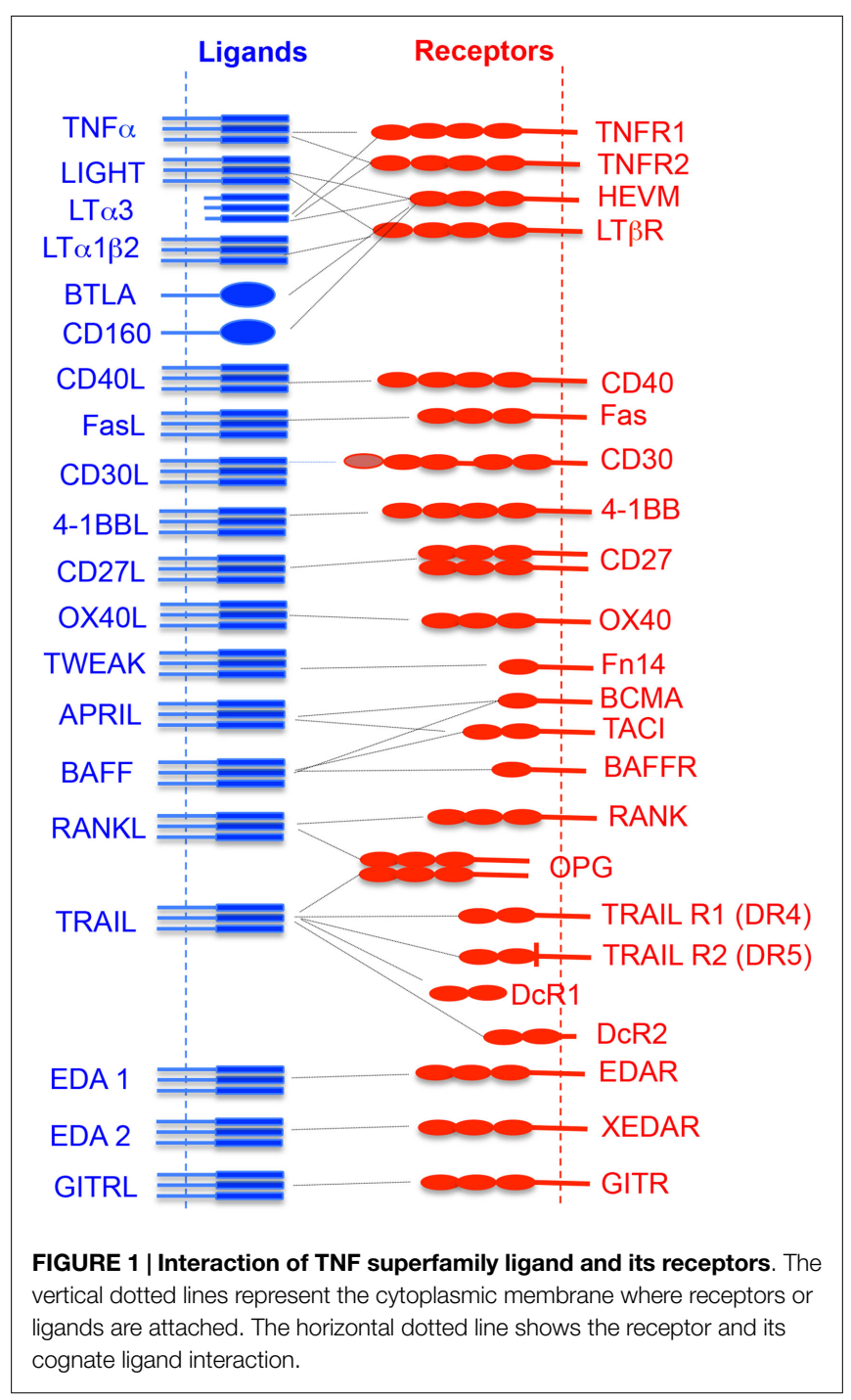

TNF receptor superfamily members are transmembrane proteins having cysteine-rich motifs in their extracellular domains that bind to their cognate ligands (Figure 1). About 30 members of TNFRSF have been identified $(3,6,7)$. Depending upon the specific intracellular signal induced by TNFRSF members, they can be categorized into three groups - death domain (DD)-containing receptors, decoy receptors, and TNF receptor-associated factor (TRAF)-binding receptors (8). Some TNFRSFs such as TNFR-1, Fas, DR3, DR4, DR5, and DR6, contain their own DDs. However, they also interact with other cytoplasmic DD-containing adaptor molecules (9). This receptor-adaptor complex acts as a scaffold for binding of immature pro-caspase, which then undergoes auto-cleavage, leading to the formation of the deathinducing signaling complex (DISC) and induction of apoptosis $(9,10)$. Some other TNFRSFs, such as TNFR-2, CD27, CD30, CD40, glucocorticoid-induced TNFR family-related gene (GITR), Fn1, lymphotoxin beta-receptor (LT $\beta R$ ), OX40, receptor activator of NF- $\kappa B$ (RANK), and XEDAR, lack a DD and contain motifs with four to six amino acids called TRAF-interacting motifs (TIMs) which recruits TRAF proteins. TRAF proteins are adaptor molecules that activate multiple downstream signaling pathways such as NF- $\kappa \mathrm{B}$, Janus kinase (JNK), ERK, p38MAPK, and $\mathrm{PI} 3 \mathrm{~K}$ that help in cell survival, proliferation, and cytokine production (11).

There are at least five anti-TNF medications (Etanercept, Infliximab, Adalimumab, Golimumab, and Certolizumab) approved by the U.S. Food and Drug Administration (FDA) for the treatment of rheumatoid arthritis (RA). Most of these biologics bind to soluble TNF molecules and prevent their binding to TNF-receptors. This blocks the production of pro-inflammatory cytokines such as IL-1, IL-6, or IFN- $\gamma$. Anti-TNF antibodies can also bind to surface-expressed TNF molecules and induce reverse signaling or antibody-induced cell death (AICD) $(12,13)$. In this review, we discuss the role of TNFSF-TNFRSF members that play a role in neuronal inflammation, the possible molecular mechanisms involved, and the efficiency of these molecules in controlling central nervous system (CNS) inflammation and autoimmunity.

The CNS is considered as an immune-privileged site and consists of a network of CNS microvessels. These microvessels are formed by a highly specialized endothelial lining supported by astrocytes, pericytes, microglial cells, and neurons, which together form a very firm blood-brain barrier (BBB). The BBB restricts entry of immune cells into the CNS, thereby actively maintaining a homeostasis. However, under inflammatory conditions, the $\mathrm{BBB}$ gets disrupted and immune cells migrate into the CNS parenchyma. A disrupted $\mathrm{BBB}$ is one of the hallmarks of autoimmune demyelinating diseases like MS and EAE (14-16).

Watts et al. have reported that vascular endothelial growth factor receptor (VEGFR) signaling activates JNK and positively regulates the angiogenesis and barrier property of $\mathrm{BBB}$ endothelial cells (17). They also reported that death receptor 6 (TNFRSF21) and TROY (TNFRSF19) were regulated in the acquisition and development of barrier property in BBB (17). Both these TNFRSF members are downstream targets of the Wnt/beta-catenin signaling pathway in the BBB endothelial cells. Dysregulation of TNFRSF21/TNFRSF19 signaling leads to the 
TABLE 1 | TNF superfamily in neuroinflammation.

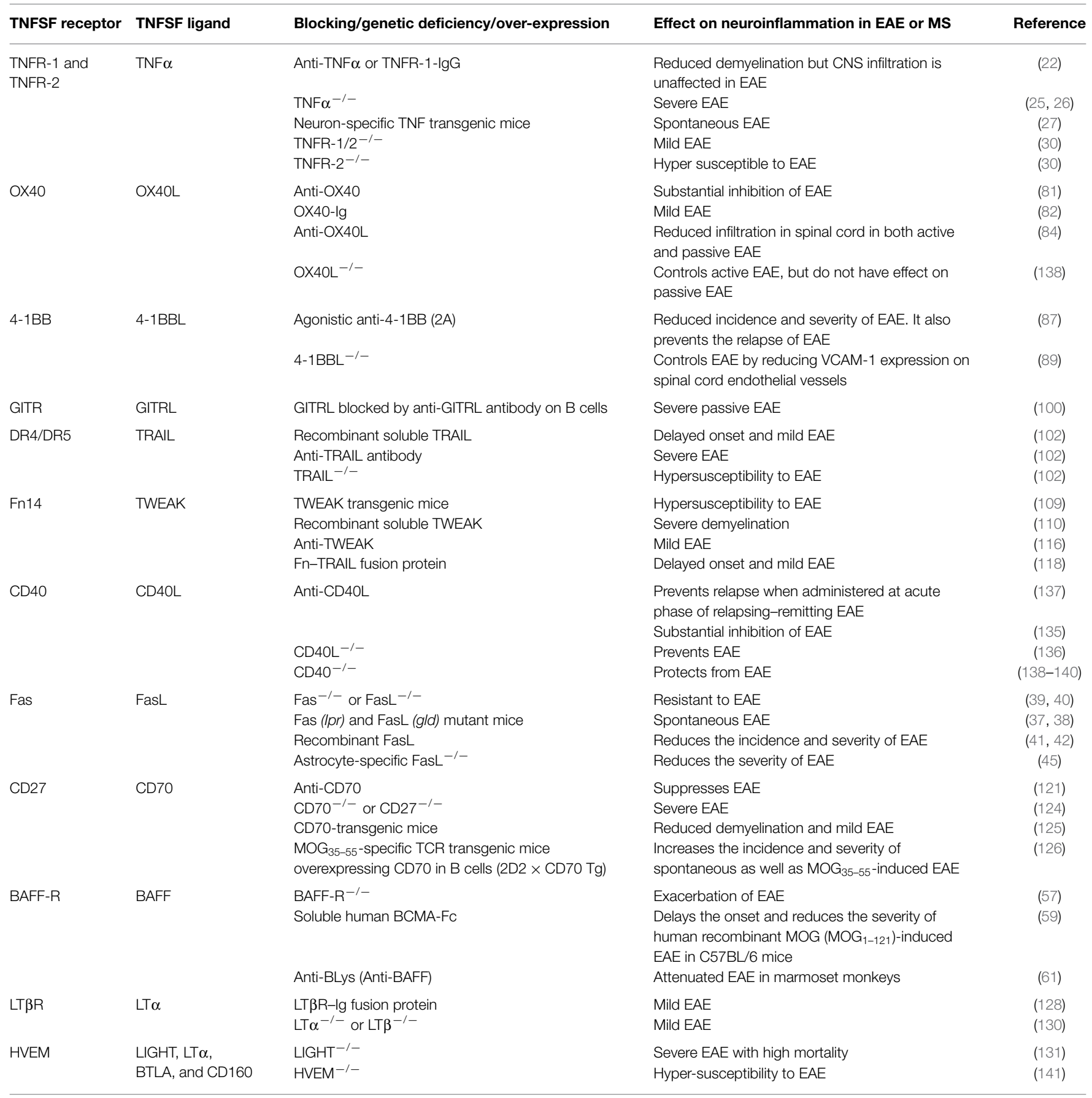

disruption of endothelial BBB. Since Wnt/beta-catenin signaling is required for CNS angiogenesis but not for peripheral vasculature $(18,19)$, an understanding of the molecular mechanism of this signaling would help in designing novel therapeutics or biologics that target TNFSF-TNFRSF interactions, to control CNS autoimmunity.

The importance of TNF superfamily receptors and ligands in neuroinflammation are listed in Table 1 . Some of the receptor-ligand interactions and their function at BBB (Figure 2) and in the brain parenchyma (Figure 3 ) are depicted. The role of important TNFSF-TNFRSF pairs in neuroinflammation and autoimmunity are discussed in details below.

\section{TNFR-TNF $\alpha$}

Tumor necrosis factor alpha (TNF $\alpha$ or TNFSF2) is a homotrimeric transmembrane protein that plays an important role in systemic inflammation. TNF $\alpha$ is expressed as a membranebound precursor $(\operatorname{tmTNF} \alpha)$, which is later cleaved between $\mathrm{Ala}^{76}-\mathrm{Val}^{77}$ by a metalloproteinase known as TNF $\alpha$-converting 


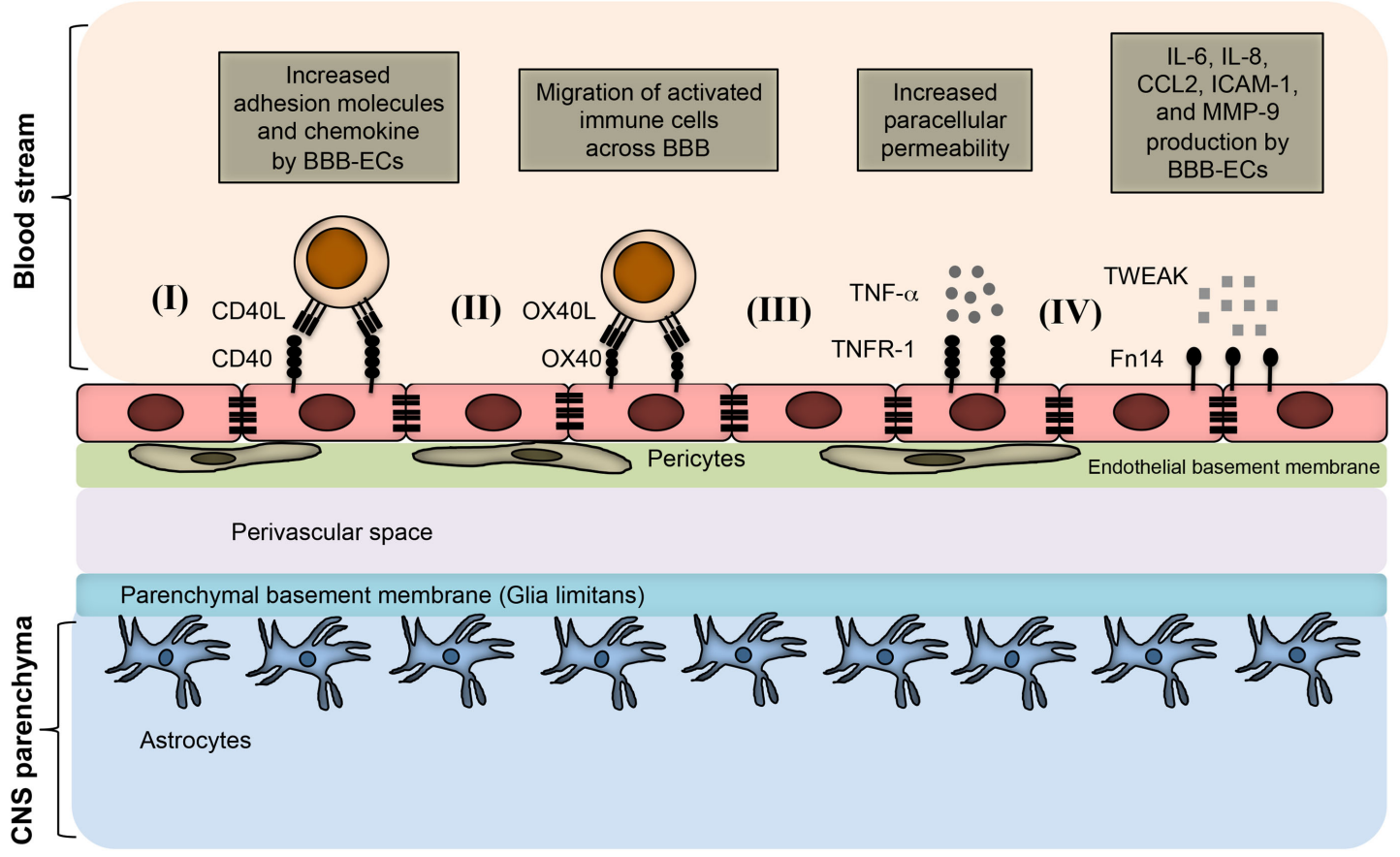

FIGURE 2 | TNFSF receptor-ligand interaction at endothelial BBB during neuroinflammation. BBB endothelial cells express TNFSF receptors during inflammatory condition, and interact with the TNFSF ligand in soluble form as well as on infiltrating immune cells. (I) Inflamed BBB endothelial cells express CD40. Interaction of CD40 with CD40L-expressing activated immune cells leads to up-regulation of adhesion molecules and chemokine secretion by BBB endothelial cells. This promotes the migration of pathogenic immune cell subsets into the CNS parenchyma. (II) OX40 expression can be induced in BBB endothelial cells during inflammation, which facilitates the migration of $\mathrm{OX}_{40 \mathrm{O}}{ }^{+}$ immune cells across the BBB. (III) Under inflammatory conditions, BBB endothelial cells up-regulate TNFR-1, which bind to soluble TNF secreted from various immune cells, such as activated Th1 cells, B cells, macrophages, and NK cells. Binding of TNF with TNFR-1 increases the paracellular permeability of BBB endothelial vessels. (IV) Inflamed BBB endothelial cells express Fn14 that binds to soluble TWEAK molecules. This leads to the up-regulation of cytokines, chemokines, cell adhesion molecules, and matrix metalloprotenase-9 (MMP-9). Increased expression of CCL2 and ICAM-1 facilitates the migration of pathogenic immune cells; whereas MMP-9 helps in the degradation of laminin molecules present in the basement membrane, resulting in loosening of the BBB. enzyme (TACE), and released as soluble TNF $\alpha$ (sTNF $\alpha$ ). TNF $\alpha$ is produced by many cell types, including activated macrophages, dendritic cells, monocytes, NK cells, $\mathrm{CD} 4^{+} \mathrm{T}$ cells, $\mathrm{CD} 8^{+} \mathrm{T}$ cells, astrocytes, and microglia (20). TNF $\alpha$ interacts with two receptors; TNF receptor type-1 (TNFR-1, also known as CD120a, p55/60) and TNF receptor type-2 (TNFR-2, also known as CD120b, p75/80). Low and constitutive expression of TNFR-1 is found on almost all nucleated cells, and can be activated by both membrane-bound TNF $\alpha(\operatorname{tmTNF} \alpha)$ and sTNF $\alpha$. However, expression of TNFR-2 is inducible and restricted to myeloid and lymphoid lineages. TNF $\alpha$ acts as a pro-inflammatory cytokine during the early phase of EAE, but shows immunosuppressive properties in the later phase. To be biologically functional, tmTNF $\alpha$ and $s T N F \alpha$ monomers must form homodimers. While both tmTNF $\alpha$ and sTNF $\alpha$ can bind to TNFR-1, sTNF $\alpha$ interacts with higher affinity than TNFR-2, leading to an inflammatory response. The tmTNF $\alpha$ mainly interacts with TNFR-2 and promotes cell survival (21). Blocking of TNF $\alpha$ by the administration of a soluble TNFR-1-IgG fusion protein or neutralization of anti-TNF $\alpha$ antibody has been shown to control the development of EAE (22). Interestingly, these biologics prevented demyelination but did not control the infiltration of immune cells into the CNS (22). Furthermore, such regimens also reduced the activation of $\mathrm{CD}^{+}{ }^{+} \mathrm{T}$ cell and microglia cells, and prevented demyelination in CNS $(23,24)$. While Korner et al. reported that a deficiency of TNF $\alpha$ only delays the disease progression and resulted in disease of comparable severity (25), others have reported that $\mathrm{TNF} \alpha$-deficient mice developed a more severe myelin oligodendrocyte glycoprotein (MOG) peptideinduced EAE as compared to wild-type littermate controls (26). Expression of TNF $\alpha$, specifically in neurons in the transgenic mice led to the development of spontaneous inflammatory demyelination (27). It has been reported that deficiency of TNF $\alpha$, LT- $\alpha$, and TNFR-1 or neutralization of TNF- $\alpha$ and LT $\alpha$ with monoclonal antibodies greatly reduced the severity of EAE (28-30). In contrast, TNFR-2-deficient mice developed more severe inflammation and demyelination in $\mathrm{MOG}_{35}-55$-induced EAE (30). Specific expression of tmTNF $\alpha$ in the transgenic mice showed reduced initiation and severity of the EAE, suggesting that selective targeting of sTNF $\alpha /$ TNFR-1 signaling may be helpful in controlling CNS autoimmunity.

In MS patients, TNF $\alpha$ were found to be expressed at very high levels in the CNS lesions and cerebrospinal fluids, but not in serum $(23,24)$, suggesting that TNF $\alpha$ was produced locally in the inflamed CNS. This indicates that TNF $\alpha$ might be a good target for therapy against MS. However, while TNF $\alpha$ 


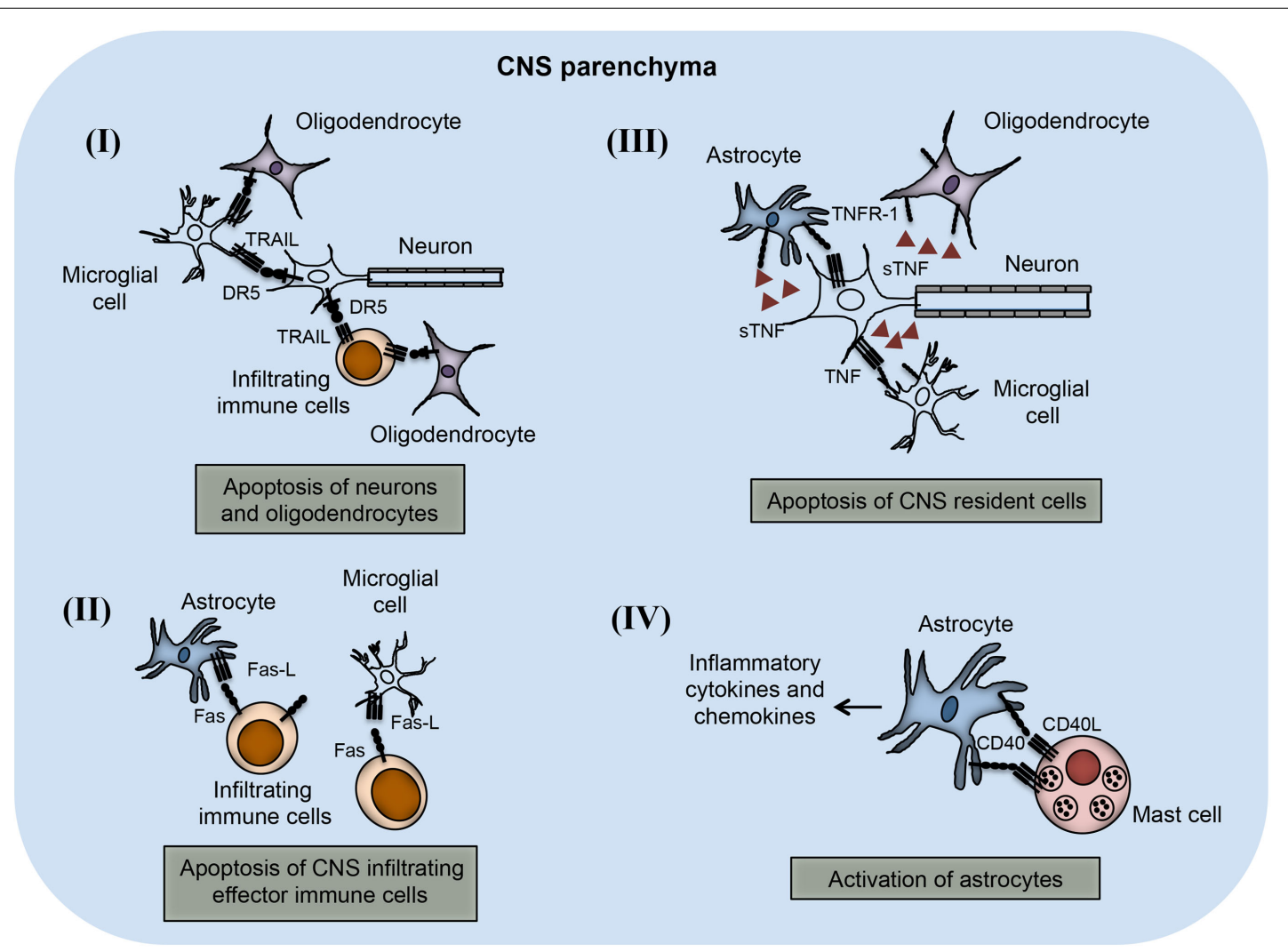

FIGURE 3 | TNFSF receptor-ligand interaction in the CNS parenchyma during neuroinflammation. TNFSF receptors and ligands are expressed on both CNS infiltrating effector immune cells and CNS-resident cells. The interaction of this receptor-ligand greatly influences the outcome of neuroinflammatory disease like multiple sclerosis and EAE. (I) Both neurons and oligodendrocytes express functional DR5 in the CNS during EAE. DR5 on the neurons as well as on oligodendrocytes interacts with TRAIL molecules present on either microglial cells or infiltrating immune cells, leading to apoptosis of DR5-expressing cells. (II) Activated astrocytes and microglial cells up-regulate FasL expression on their surface. The inhibitors showed protection in the mouse model of EAE, adverse effects were observed during clinical trials in MS patients (21). Similarly, a clinical trial with TNFR-1 fusion protein in MS patients showed disease exacerbation, and the trial was stopped (31). This increased demyelination with TNF $\alpha$ antagonist might be due to the several possible reasons such as: (a) down-regulation of anti-inflammatory cytokine IL-10 and increased production of inflammatory cytokine IL-12 and IFN- $\gamma(32,33)$; (b) downregulation of TNFR-2, which is known to regulate the proliferation of oligodendrocytes and damage repair (34); (c) possibility of reduced or non-permeability of the BBBs to TNF $\alpha$ blockers which would prevents their direct action through these molecules could still enhance the disease by increasing auto-reactive $\mathrm{T}$ cells in the peripheral tissues, which can migrate into the CNS and damage the tissues (35); (d) unmasking of latent infection, which is critical for inducing the autoimmune demyelination reaction (36). AntiTNF $\alpha$ therapy has also been used to control other autoimmune diseases such as RA. However, keeping in mind the possibility of demyelination of the central and peripheral neuronal tissues by interaction of FasL with Fas-expressing cells leads to apoptosis and elimination of pathogenic effector immune cells. (III) Neuronal cells express TNF and that can interact with TNFR-1 present on various CNS-resident cells, such as astrocytes, microglial cells, and oligodendrocytes. Interactions of TNF with TNFR-1-expressing cells lead to apoptosis of TNFR-1 ${ }^{+}$cells. (IV) Mast cells are known to localize close to the astrocytes during EAE in the brain. CD40L present on mast cells interact with CD40-expressing astrocytes, which induces increased production of inflammatory cytokines and chemokines. Local production of inflammatory molecules can augment inflammation and tissue damage in the CNS. such therapy, caution must be exercised, and careful monitoring of any pre-existing neuronal disease or its development following treatment with TNF $\alpha$ antagonists would be prudent.

\section{Fas-FasL}

Fas ligand (FasL, also known as CD95L, TNFSF6) is a type II transmembrane protein expressed on a variety of cells, including CD8 ${ }^{+}$ $\mathrm{T}$ cells and oligodendrocytes. It binds to the Fas receptor (Fas, also known as CD95, TNFRSF6, apoptosis antigen 1) and the decoy receptor 3 (DcR3). FasL-Fas interactions lead to the formation of a DISC in the Fas-expressing cells, leading to induction of apoptosis. The interaction of Fas with FasL on CNS infiltrating cells or activated CNS-resident cells (microglia, astrocytes, and neurons) also leads to the induction of apoptosis. FasL-Fas interactions play a very important role in immune cell homeostasis, and its dysregulation leads to various autoimmune diseases. Mice with autosomal recessive mutations in Fas (lymphoproliferative, lpr mice; lack Fas expression) and FasL (generalized lymphoproliferative disease, gld 
mice; lack FasL expression) genes develop a spontaneous autoimmune syndrome; produce autoantibodies and accumulate a large number of $\mathrm{CD}^{-} \mathrm{CD}^{-} \mathrm{T}$ cells in the secondary lymphoid tissues, leading to the progressive development of lymphadenopathy and splenomegaly $(37,38)$. Fas and FasL-deficient mice are resistant to MOG-induced EAE, compared to wild-type mice $(39,40)$, and intrathecal injection of recombinant FasL protein or neutralizing with anti-FasL antibody suppresses acute EAE $(41,42)$. Adoptive transfer of myelin basic protein (MBP)-specific FasL ${ }^{-1-} \mathrm{CD} 4$ $\mathrm{T}$ cells in the wild-type host showed reduced EAE pathology suggesting that FasL expression regulates the encephalitogenic function of $\mathrm{T}$ cells (43). It would be interesting to study how these auto-reactive $\mathrm{CD}^{+}{ }^{+} \mathrm{T}$ cells cross $\mathrm{BBB}$ and cause neuronal tissue damage. Determining the temporal and site-specific expression of FasL in a variety of CNS-resident cells during ongoing neuroinflammation might provide valuable clues to address this question. It has been also reported that Lpr mice on SJL/J background are completely susceptible to the proteolipid protein ( $\left.\mathrm{PLP}_{139-51}\right)$ induced EAE (40). This discrepancy might be due to the involvement of other effector pathways mediated by various TNFRSF members in the CNS.

Astrocytes constitutively express FasL, and they show both positive and negative roles in the inflammation and the development of EAE (44). Using targeted deletion of FasL, specifically in astrocytes, Wang et al. showed that astrocytic FasL is required for the elimination of auto-reactive $\mathrm{T}$ cells in the CNS (45). Gamma-delta $(\gamma \delta) \mathrm{T}$ cells play a very important role in EAE (46), and their deficiency results in chronic EAE (47). $\gamma \delta$ T cells were shown to regulate CNS inflammation and disease recovery in a FasL-Fas-dependent manner by controlling the encephalitogenic $\mathrm{CD}^{+}{ }^{+} \mathrm{T}$ cells (47). Collectively, these reports suggest that Fas-FasL-mediated apoptosis acts as an intrinsic regulatory mechanism to control neuroinflammation and development of CNS autoimmunity.

\section{BAFF-R-BAFF}

The B-cell activating factor of the tumor necrosis factor family (BAFF; also known as TNFSF13B, CD257, B lymphocyte stimulator "BLys"), was originally described as a molecule secreted by $\mathrm{T}$ cells and dendritic cells that provide maturation and survival signals to peripheral B cells (48). Its expression was also reported in other cell types such as macrophages, dendritic cells, and neutrophils (49). BAFF transgenic mice have elevated numbers of $\mathrm{B}$ cells and effector $\mathrm{T}$ cells, and show symptoms similar to that seen in B-cell-mediated autoimmune diseases (50). Immature $\mathrm{B}$ cells in the bone marrow express BAFF-receptor (BAFF-R), and its expression is also up-regulated during the development from transitional B-cell stage to mature B cell in the secondary lymphoid organs $(51,52)$. BAFF also interacts with two more known receptors expressed on the B cells; transmembrane activator calcium modulator and cyclophilin ligand interactor (TACI) and B-cell maturation factor (BCMA) (53). TACI is known to be expressed on marginal zone $\mathrm{B}$ cells, and BCMA on germinal center B cells, plasma cells, and memory B cells (54). In addition to BAFF, TACI and BCMA are also known to interact with another
TNFSF member known as APRIL $(55,56)$. Genetic deficiency of BAFF-R in mice resulted in hyper-susceptibility to $\mathrm{MOG}_{35-55}$ peptide-induced EAE (57), suggesting that this receptor has a regulatory function in EAE. It has been reported that defects in the BAFF-BAFF-R signaling adversely influence the regulatory Bcell (Breg) function, inducing early onset and severe pathology of the disease (58). Huntington et al. showed that administration of $\mathrm{hBCMA}-\mathrm{Fc}$ fusion protein in C57BL/6 mice not only reduced the $\mathrm{B}$-cell numbers in peripheral blood, lymph nodes, and spleen, and resulted in a reduced titer of MOG-specific antibody in the serum but it also hampered the activation and differentiation of $\mathrm{CD} 4^{+}$ $\mathrm{T}$ cells (59). It has also been reported that BAFF can enhance the auto-reactive Th17 response, leading to increased progression of EAE (60). Antibody-mediated blocking of BAFF with anti-human BLys attenuated the EAE in marmoset monkeys (61). Glatiramer acetate (GA) is the approved frontline drug for the treatment of EAE and MS, which acts on both innate as well as $\mathrm{T}$ and $\mathrm{B}$ cells during EAE, and induces an anti-inflammatory microenvironment in the neuronal tissue (62-65). GA was also shown to reduce BAFF mRNA expression in the brain, and decrease the number of BAFF- ${ }^{+} \mathrm{B}$ cells, but not the $\mathrm{TACI}^{+} \mathrm{B}$ cells in the spleen of EAE mice (66). These reports clearly indicate that BAFF-BAFF-R signaling contributes to the pathogenesis of EAE, and its perturbation may provide a valuable therapeutics tool to control CNS autoimmunity.

\section{OX40-OX40L}

The OX40 (also known as ACT35, CD134, TNFRSF4) is a type I glycoprotein of $\sim 50 \mathrm{kD}$, which is expressed on activated $\mathrm{T}$ cells, such as Th1, Th2, Th17, Foxp $3^{+}$regulatory CD4 ${ }^{+} \mathrm{T}$ cell (Treg), and $\mathrm{CD}^{+} \mathrm{T}$ cells (67). The OX40 ligand (OX40L also known as gp34, CD252, TNFSF4) is a type II glycoprotein expressed on APCs, such as dendritic cells, B cells, macrophages, and endothelial cells (68). The interaction of OX40-OX40L provides a costimulatory signal to $\mathrm{T}$ cells, which leads to their activation and cytokine secretion (69). Inhibiting OX40-OX40L interactions protects from many inflammatory autoimmune diseases, including $\mathrm{EAE}(70,71)$. OX40-OX40L signaling in $\mathrm{CD}^{+}{ }^{+} \mathrm{T}$ cells promotes the expression of IL-12R $\beta 2$ (72) while inhibits the expression of CTLA-4 (73), Foxp3 (74-76), and IL-10 (77). Selective up-regulation of IL-12R $\beta 2$ leads to the differentiation of Th1, whereas loss of Foxp3, CTLA-4, and IL-10 inhibits the suppressive function of Tregs. Thus, the loss of balance between pathogenic and regulatory cells could promote autoimmune pathology. A growing body of evidences suggests that OX40-OX40L interactions regulate the differentiation of $\mathrm{CD}^{+}{ }^{+} \mathrm{T}$-cell subsets, and deficiency of OX40 impairs Treg development (78). This might be because the reverse signaling through OX40L in APCs leads to the production of cytokines IL- 6 and IL-12, which regulates the differentiation of effector $\mathrm{CD}^{+}{ }^{+} \mathrm{T}$ cells (68). It has been shown that OX40L-OX40 signaling inhibits Foxp3 expression $(75,79)$, and acts as a strong differentiating factor for Th9 in airway inflammation (80). These studies suggest that OX40-OX40L signaling could promote inflammatory responses, in addition to suppressing anti-inflammatory responses in $\mathrm{CD}^{+} \mathrm{T}$ cells $(68,78)$. All 
these observations suggest that functional plasticity of the $\mathrm{CD} 4^{+}$ T-cell subsets is also controlled by OX40L-OX40 interactions.

OX40-OX40L interactions in CD28-deficient mice initially led to the identification of OX40-OX40L signaling as being costimulatory in EAE, and blocking these interaction-protected mice from EAE (71). In the rat EAE model, pathogenic OX40 ${ }^{+}$ $\mathrm{CD}^{+}{ }^{+} \mathrm{T}$ cells were found in CNS lesions, and neutralization of OX40 by anti-OX40 antibody ameliorated the EAE (81). Targeting OX40-OX40L interaction with an OX40-Ig fusion protein at the onset of EAE greatly reduced the severity of the disease (82). Brain endothelial cells are the central component of the BBB and are known to express OX40L, which recruit $\mathrm{OX} 40^{+}$auto-reactive T cells into the CNS (82). OX40 treatment of human umbilical cord endothelial cells (HUVECs) lead to the up-regulation of CCL5, suggesting that this signaling also modulates endothelial cells to attract a selective population of immune cells at the BBB (83). It would be interesting to study whether OX40 signaling affects the expression of cell adhesion molecules, chemokines, and integrins in the brain endothelial cells. Blocking OX40L by anti-OX40L antibody reduces the infiltration of OX40 ${ }^{+}$myelinspecific $\mathrm{T}$ cells in the spinal cord without affecting the priming of the myelin-specific $\mathrm{CD} 4^{+} \mathrm{T}$ cells in the draining lymph nodes in active as well as passive EAE (84). Therefore, OX40-OX40L not only controls the activation and differentiation of $\mathrm{CD} 4^{+} \mathrm{T}$ cells, but also potentiates their migration into the CNS. Together, these reports indicate that OX40-OX40L supports the development of neuroinflammation and CNS autoimmunity.

\section{4-1BB (CD137) - 4-1BBL (CD137L)}

4-1BB (TNFRSF9) is expressed on activated CD4 ${ }^{+} \mathrm{T}$ cells (Th1, Th2, and Treg), CD8 ${ }^{+} \mathrm{T}$ cells, B cells, dendritic cells, NK cells, NKT cells, and mast cells, whereas its ligand, 4-1BBL, is expressed on activated APCs (macrophages, B cells, and dendritic cells), $\mathrm{CD}^{+}{ }^{+}$and $\mathrm{CD}^{+}{ }^{+} \mathrm{T}$ cells, NK cells, mast cells, and smooth muscle cells (85). Under inflammatory condition, neurons are also known to express 4-1BBL (3). B7-deficient APCs deliver the costimulatory signal to $\mathrm{CD} 4{ }^{+} \mathrm{T}$ cells through $4-1 \mathrm{BBL}$ in a TRAF2dependent manner (86). It has been reported that stimulation of human $\mathrm{CD}^{+} \mathrm{T}$ cells with 4-1BBL leads to the production of effector molecules such as perforin and granzyme (3). Antibody treatment with agonist anti-4-1BB (2A) in induced EAE resulted in milder disease, but failed to control the development of passive EAE by adoptive transfer of $\mathrm{MOG}_{35-55}$-specific $\mathrm{CD}^{+} \mathrm{T}$ cells (87). Anti-4-1BB (2A) treatment induced IFN- $\gamma$ and granulocyte-macrophage colony-stimulating factor (GM-CSF) secretion by $\mathrm{MOG}_{35-55}$-specific $\mathrm{CD}^{+}{ }^{+} \mathrm{T}$ cells, leading to differentiation of inflammatory Th1 (87). It has been suggested that targeting 4-1BB or 4-1BB ligand could lead to the induction of unresponsiveness in the $\mathrm{CD}^{+}$T cells during EAE $(88,89) .4-1 \mathrm{BBL}^{-1-}$ mice showed reduced expression of vascular cell adhesion molecule-1 (VCAM1) on spinal cord endothelial vessels, which play an important role in the migration of immune cells in the inflamed CNS (89). 4$1 \mathrm{BBL}$ downstream signaling induced the production of reactive oxygen species (ROS) in microglia, leading to apoptosis of oligodendrocytes in the EAE (85). Therefore, these studies indicate that
4-1BB-4-1BBL interactions not only promote the activation of $\mathrm{T}$ cells, but also control the migration of myelin-specific $\mathrm{CD} 4^{+} \mathrm{T}$ cells in the CNS. Furthermore, 4-1BBL signaling has a destructive role in the inflamed CNS during EAE.

\section{GITR-GITRL}

Glucocorticoid-induced TNFR family-related gene (also known as CD357, TNFRSF18) is expressed at the low levels in resting mouse and human T cells, but is up-regulated on activated CD4 ${ }^{+}$ and $\mathrm{CD}^{+}{ }^{+} \mathrm{T}$ cells. GITR is constitutively expressed on Tregs $(90,91)$. GITR-GITRL interactions inhibit the suppressive function of $\mathrm{CD}^{+}{ }^{+} \mathrm{CD} 25^{+}$Tregs and therefore, blocking these interactions breaks the peripheral immune tolerance (92). GITRL is expressed at the low levels on B cells, macrophages, bone marrowderived dendritic cells, and endothelial cells (3). GITRL can act as a costimulatory signal to $\mathrm{CD} 4{ }^{+} \mathrm{CD} 25^{-}$and $\mathrm{CD} 4{ }^{+} \mathrm{CD} 25^{+} \mathrm{T}$ cells (93), and to $\mathrm{CD}^{+} \mathrm{T}$ cells in the presence of suboptimal concentrations of anti-CD3 $\varepsilon$, in the absence of CD28-mediated signaling (94). In addition, signaling through GITR stimulates the production of cytokines such as IFN- $\gamma$, IL-2, IL-4, and IL-10 in $\mathrm{CD}^{+}{ }^{+} \mathrm{T}$ cells (95).

Regulatory B cells are known to produce anti-inflammatory cytokine IL-10 (96) and suppress CNS autoimmunity (97). Transgenic mice constitutively expressing GITRL on B cells (GITRL $^{+}$B cells) showed a significantly higher numbers of peripheral Tregs, suggesting that GITRL ${ }^{+} \mathrm{B}$ cells might play a role in the homeostasis of Tregs (99). Animals that received, B cells pre-treated with anti-mouse GITRL antibody showed significantly decreased Tregs induction and severe EAE, suggesting that GITRL ${ }^{+}$B cells support the proliferation and homeostasis of Tregs (100). Treatment with Rituximab, a monoclonal antibody that depletes B cells, including Bregs, leads to severe exacerbation of human ulcerative colitis, suggesting that Bregs play an important role in controlling CNS autoimmunity (98). A peripheral increase in Treg frequency can inhibit the proliferation of myelinspecific effector $\mathrm{CD} 4^{+} \mathrm{T}$-cell subsets in the secondary lymphoid organs, and can therefore control CNS autoimmunity. This clearly indicates that B cells, through the expression of GITRL, promote and maintain the expansion of Tregs and contribute to the maintenance of immune tolerance.

\section{DR4/5-TRAIL}

TNF-related apoptosis-inducing ligand (also known as CD253, TNFSF10) is a type II membrane protein that binds to two death receptors, DR4 (TRAIL-RI) and DR5 (TRAIL-RII). These receptors are known to induce apoptosis in various cell types in a caspase-dependent manner. Both DR4 and DR5 are known to be expressed in humans, whereas mice express only DR5 (101). TRAIL also binds to the decoy receptors, DcR1 (lack cytoplasmic domain) and DcR2 (truncated DD). Rather than inducing apoptosis, binding to these receptors induces $\mathrm{NF} \kappa \mathrm{B}$ activation. TRAIL receptors are expressed in neurons and oligodendrocytes, but TRAIL is completely undetected in a healthy CNS. Signaling from TRAIL-DR4/5 is implicated in the pathogenesis of MS and EAE (101). TRAIL is generally found on infiltrating 
immune cells and activated microglia in the MS lesions. The DR4/DR5-TRAIL interaction seems to induce oligodendrocyte and neuronal death during ongoing EAE. TRAIL-induced apoptosis of neurons and oligodendrocytes contribute to the development of brain inflammation. Blocking brain-specific TRAIL leads to a reduction in the severity of EAE. Similarly, therapeutic treatment with soluble TRAIL delays the onset of the disease and reduces its severity (102). TRAIL is also reported to inhibit Th1 response and promote the suppressive function of Tregs (103). Genetically modified dendritic cells (ES-DCs), which can simultaneously present MOG peptides in association with MHC-II and express TRAIL, cause a reduction in the severity of EAE induced by both MOG $_{35-55}$ and MBP $(104,105)$. One of the mechanisms through which these ES-DCs controls EAE is by promoting the proliferation of $\mathrm{CD} 4{ }^{+} \mathrm{CD} 25^{+}$Tregs, which suppress myelin-specific effector $\mathrm{CD} 4^{+} \mathrm{T}$-cell responses. It might be possible that TRAIL signaling has a dual role; it may promote suppressive phenotype in the secondary lymphoid organs, whereas in local inflamed CNS, it contributes to tissue damage. Therefore, delineating the role of TRAIL signaling in a spatio-temporal manner during the neuroinflammatory events might help in understanding the complexity of CNS autoimmunity. Osteoprotegerin (OPG), a secreted protein under physiological conditions, shows a lower binding affinity for TRAIL (106); however, its role in CNS inflammation and autoimmunity is not well studied. All these studies suggest that, the apoptosis-inducing property of TRAIL in inflamed CNS contributes to the development of inflammation and CNS autoimmunity.

\section{TWEAK-Fn14}

TNF-like weak inducer of apoptosis (TWEAK; TNFSF12) is a pro-inflammatory and pro-angiogenic cytokine synthesized as a type II transmembrane protein. However, it can be cleaved to give rise to soluble cytokine (107). Both membrane-bound and soluble TWEAK bind to the only known receptor, fibroblast growth factor-inducible 14 (Fn14; also known as TNFRSF12A). TWEAK is expressed on monocytes, microglia, and astrocytes in the healthy CNS. Its expression goes up during CNS inflammation. Fn14 is also expressed on CNS-resident cells such as brain endothelial cells, astrocytes, and neurons $(108,109)$. Overexpression of soluble TWEAK by injecting TWEAK-encoding recombinant plasmid (110), or in TWEAK transgenic animals resulted in increased severity of EAE (109). These studies indicate that local expression of TWEAK and Fn14 in the CNS could be a critical contributing factor to the pathology of neuroinflammation. One of the mechanisms by which TWEAK elevates CNS inflammation is by inducing CCL2 secretion from brain endothelial cells and astrocytes. CCL2 is a potent activator of neuroinflammation, and plays an important role in the pathogenesis of EAE and MS $(111,112)$. TWEAK-Fn14 signaling in BBB endothelial cells compromises its barrier property in the mouse models of cerebral ischemia. Therefore, it is possible that during neuroinflammation such interactions can affect the $\mathrm{BBB}$, allowing the myelin-specific cells and soluble mediators to enter into the CNS parenchyma $(113,114)$.
TWEAK-Fn14 binding does not induce ligand-activated kinase signaling due to lack of cytoplasmic DD, but it triggers the engagement of the TRAF, an adaptor protein that activates the ERK1/2, PI3K/Akt, and NF- $\kappa B$ signaling pathways. Membranebound TWEAK is a more powerful inducer of the classical NF$\kappa \mathrm{B}$ signaling pathway than its soluble forms (115). It has been shown that inhibition of TWEAK-Fn14 signaling decreases the severity of EAE $(110,116)$ and CIA (117). Neutralization of TWEAK after the priming phase with monoclonal antibody controls immune cell infiltration into the neuronal tissues and reduce the pathology of EAE (116). An immunotherapeutic fusion protein, Fn14-TRAIL consists of a portion of Fn14 receptor fused with the TRAIL ligand, which blocks the function of TWEAK. In vivo expression of this soluble functional chimera was shown to control the EAE (118). A functional analysis of T-cell response in these mice showed decreased effector Th1 and Th17 responses, and increased number of suppressive Tregs, suggesting that the balance was shifted more toward immune tolerance, which controls the EAE (119). These studies suggest that TWEAK is a very good therapeutic target to control neuroinflammation and autoimmunity. Currently, several TWEAK-targeting therapeutic agents are in clinical trials for autoimmunity and cancer (107).

\section{CD70-CD27}

The CD70 (CD27L, also known as TNFSF7) is a homotrimeric type II transmembrane glycoprotein, and known to express on $\mathrm{B}$ cells, T cells, mast cells, NK cells, and activated dendritic cells. It is also expressed on epithelial cells in the thymic medulla. CD70 mainly resides in the endosomal compartment. Its expression is activation-dependent, and controlled by the master transcription regulator of MHC class II gene, CIITA. CD70 binds to its receptor CD27 (TNFRSF7) expressed on $\mathrm{CD}^{+}$and $\mathrm{CD}^{+}{ }^{+} \mathrm{T}$ cells, and provides a costimulatory signal, which leads to the proliferation and survival of activated B and T cells. The CD27-CD70 interaction also controls effector and memory responses, and prevents the induction of tolerance (120). Treatment of animals with antiCD70 antibody suppresses the EAE, possibly by inhibiting the TNF- $\alpha$ production by draining lymph node cells (121). CD70transgenic mice showed increased numbers of IFN- $\gamma$-producing $\mathrm{CD}^{+}{ }^{+}$and $\mathrm{CD}^{+} \mathrm{T}$ cells, suggesting that CD70-CD27 signaling controls Th1 (120). It has been reported that $\mathrm{CD} 27^{+} \gamma \delta$ $\mathrm{T}$ cells express high levels of IFN- $\gamma$ and lower levels of IL-17, whereas $\mathrm{CD}^{-} 7^{-} \gamma \delta \mathrm{T}$ cells express lower levels of IFN- $\gamma$ and high levels of IL-17, suggesting that CD27 essentially controls the differentiation of $\gamma \delta$ T cells, which gives rise to two different effector subsets of $\gamma \delta$ T cells $(46,122,123)$. The deficiency of CD27 and CD70 in animals leads to significantly increased EAE. In contrast, CD70-Tg mice showed reduced EAE pathology $(124,125)$. Furthermore, Coquet el al. reported increased Th17 response in $\mathrm{CD}_{27}^{-/-}$and $\mathrm{CD} 70^{-/-}$, and reduced Th17 in CD70Tg mice (124). They concluded that this increased Th17 differentiation in $\mathrm{CD} 27^{-1-}$ and $\mathrm{CD} 70^{-1-}$ animals were due to increased phosphorylation of the JNK and epigenetic modification at IL17 locus, suggesting that CD70-CD27 signaling directly controls the Th17 response in $\mathrm{CD}^{+} \mathrm{T}$ cells (124). Interestingly, antiCD70 antibody-mediated blocking of CD70 prevented EAE in 
SJL/J mice (121), and over-expression of CD70 on the B cells enhanced EAE (126). This is in contrast to what is reported by Coquet et al. (124). These discrepancies might be due to the differences in the mouse strains used or in the cell types where CD70-Tg was over expressed, since over-expression of CD70 in B cells leads to hyper-activation of T cells and a gradual loss of B cells (127). CD70 signaling affects the expression of IL-17F and CCR6 but not other Th17-associated molecules such as RORs, BATF, and IL-23R (124), suggesting that targeting CD27 may be beneficial in controlling effector CD4 ${ }^{+}$T-cell differentiation and its migration into the inflamed tissues during autoimmunity.

\section{LT $\beta R-L T \alpha$}

Lymphotoxin alpha (also known as TNFSF1) exists as a secreted homotrimeric molecule produced by lymphocytes. LT $\alpha$ also forms a membrane-anchored heterotrimer with LT $\beta$ (Figure 1). LT $\alpha$ homotrimer $\left(\mathrm{LT}_{3}\right)$ interacts with TNFR-1, TNFR-2, and herpes virus entry mediator (HEVM), whereas the heterotrimer molecule $\left(\mathrm{LT} \alpha_{1} \beta_{2}\right)$ interacts with the LT $\beta \mathrm{R}$ (also known as TNFRSF3) (Figure 1). LT $\beta \mathrm{R}$ is expressed on most cell types, including epithelial cells, endothelial cells, and cells of the myeloid lineages, but not on B and T lymphocytes. LT levels were known to increase in the CNS before the onset of clinical signs of EAE, suggesting a role in the pathogenesis of CNS inflammation. Treatment with LT $\beta$ R-Ig fusion protein alters the localization of leukocytic infiltration into the CNS and controls the EAE (128). $\mathrm{LT} \alpha^{-1-}$ mice have developmental defects in the lymph node formation, and lack Peyer's patches (129). LT $\alpha^{-1-}$ mice show reduced demyelination and $\mathrm{CNS}$ inflammation in $\mathrm{MOG}_{35-55^{-}}$ induced EAE. However, adoptive transfer of $\mathrm{MOG}_{35}-55$-specific wild-type T cells induces EAE (130). This indicates that LT-LT $\beta R$ signaling mainly regulates the priming phase of myelin-specific T-cell activation and development, but not the actual homing of these auto-reactive cells into the inflamed CNS. In contrast, $\mathrm{LT}^{-1-}$ mice develop $\mathrm{MOG}_{35-55}$-induced EAE, but to a somewhat lesser extent as compared to wild-type animals. These results suggest that LT $\alpha$ plays a very important role in the development of EAE (130). LIGHT (CD258, also known as TNFSF14) is a potent, CD28-independent costimulatory molecule expressed on $\mathrm{T}$ cells that are involved in initial T-cell priming and expansion. LIGHT can interact with both LT $\beta$ R and HEVM. Interaction of LIGHT with HVEM has a costimulatory function, whereas its interaction with LT $\beta$ R induces apoptosis. LIGHT-deficient mice develop more severe $\mathrm{MOG}_{35-55}$-induced EAE due to intensive activation of microglia/macrophages and increased frequency of apoptotic cells within the CNS parenchyma, as compared to wild-type animals (131). Expression of LIGHT on CNS-resident cells rather than myelin-specific $\mathrm{CD} 4^{+} \mathrm{T}$ cells is the most crucial factor in the pathogenesis of EAE. This also suggests that LIGHT expression plays an important role in controlling the activated microglia/macrophages during CNS inflammation. Therefore, selective targeting of LIGHT-HVEM signaling may provide protection against neuroinflammation and CNS autoimmunity. However, the involvement of LIGHT-HVEM interactions with other CNS-resident and infiltrating cells is not well characterized.
It would be interesting to study these interactions in different stages of neuroinflammation.

\section{CD40-CD40L}

The CD40 ligand (CD154, also known as TNFSF5) is expressed on activated $\mathrm{T}$ cells, and binds to its cognate receptor CD40 (TNFRSF5) on APCs. CD40L-CD40 interactions lead to the activation of $\mathrm{B}$ cells, their differentiation into plasma cells, and immunoglobulin class switching. The CD40L-CD40 interactions play a very important role in many autoimmune diseases. The disruption or blocking of this interaction inhibits clinical manifestation and ameliorates the EAE in mice and monkeys (132, 133). In the CNS, various cells, including astrocytes and glial cells express CD40, and expression of this molecule is required for the development of $\operatorname{EAE}(133,134)$. It has been reported that blocking of CD40L-CD40 interaction controls the development of $\operatorname{EAE}(135,136)$. Treatment of animals with remitting EAE in this manner not only controls the EAE, but also inhibits the longterm delayed type hypersensitivity (DTH) response (137). One study has reported that mast cells and astrocytes are localized together in the inflamed CNS, and they have potential to interact with each other via CD40L on mast cells and CD40 on astrocytes (134). In vitro studies have shown that this interaction activates astrocytes leading to the secretion of cytokines. These cytokines act in an autocrine manner, and potentiate multiple signaling via the JAK-STAT-1 $\left(\mathrm{Tyr}^{701}\right)$ pathway in the astrocytes (134). Therefore, a contributing signaling event that can enhance the function of infiltrating effector immune cells as well as CNSresident cells may also promote axonal damage. These reports suggest that CD40-CD40L costimulatory signaling contributes to neuroinflammation and CNS autoimmunity.

\section{Future Perspective}

The growing body of evidence demonstrated that TNF-TNFR interactions are involved in the pathogenesis of EAE and MS. These interactions control the disease outcome by fine-tuning the peripheral immune response as well as interactions between CNS-resident cells and effector immune cells in the CNS. Several reports suggest that the TNFSF-TNFRSF pairs that signal the promotion of inflammation are OX-40-OX40L, sTNF $\alpha-$ TNFR1, CD27-CD70, 4-1BB-4-1BBL, Fn14-TWEAK, CD40-CD40L, and LT- $\alpha / \mathrm{LT} \beta-\mathrm{LT} \beta \mathrm{R}$; whereas the ones that show a protective role are tmTNF $\alpha$-TNFR-2, DR4/DR5-TRAIL, and HVEM-LIGHT. Conflicting results have been reported in the literature about some of the interactions and their importance in CNS autoimmunity. These discrepancies in the results reported by different investigators may be due to the differences in the animal models used or immunization strategies employed to induce the EAE. Furthermore, cross-talks between the signaling induced by various TNFSF-TNFRSF may also contribute to the pathogenesis of disease. Keeping in mind that the combination therapy is central to immunotherapeutic approaches, understanding how and when to block TNFSF-TNFRSF interactions, individually or in combination with other targets, depends on our in-depth knowledge of their expression patterns and molecular mechanisms. 
Since, there are several TNF superfamily members that have the ability to influence neuroinflammation one way or another, reaching a decision about targeting one or more receptor-ligand pairs at a given time for clinical application requires further investigation. A better understanding of their expression profile, and kinetics of expression, and interactions between TNF ligands and their TNFRs on various CNS residents and infiltrating immune cells at different stages of the disease would help to design better strategies to control neuroinflammation and CNS autoimmunity.

\section{References}

1. Matsumoto M. Role of TNF ligand and receptor family in the lymphoid organogenesis defined by gene targeting. J Med Invest (1999) 46:141-50.

2. Ronchetti S, Nocentini G, Petrillo MG, Bianchini R, Sportoletti P, Bastianelli A, et al. Glucocorticoid-induced TNFR family related gene (GITR) enhances dendritic cell activity. Immunol Lett (2011) 135:24-33. doi:10.1016/j.imlet. 2010.09.008

3. Watts TH. TNF/TNFR family members in costimulation of $\mathrm{T}$ cell responses. Annu Rev Immunol (2005) 23:23-68. doi:10.1146/annurev.immunol.23. 021704.115839

4. Vincent FB, Morand EF, Schneider P, Mackay F. The BAFF/APRIL system in SLE pathogenesis. Nat Rev (2014) 10(6):365-73. doi:10.1038/nrrheum.2014.33

5. Croft M, Duan W, Choi H, Eun SY, Madireddi S, Mehta A. TNF superfamily in inflammatory disease: translating basic insights. Trends Immunol (2012) 33:144-52. doi:10.1016/j.it.2011.10.004

6. Croft M. The role of TNF superfamily members in T-cell function and diseases. Nat Rev Immunol (2009) 9:271-85. doi:10.1038/nri2526

7. Croft M, Benedict CA, Ware CF. Clinical targeting of the TNF and TNFR superfamilies. Nat Rev Drug Discov (2013) 12:147-68. doi:10.1038/ $\operatorname{nrd} 3930$

8. Dempsey PW, Doyle SE, He JQ, Cheng G. The signaling adaptors and pathways activated by TNF superfamily. Cytokine Growth Factor Rev (2003) 14:193-209. doi:10.1016/S1359-6101(03)00021-2

9. Wilson NS, Dixit V, Ashkenazi A. Death receptor signal transducers: nodes of coordination in immune signaling networks. Nat Immunol (2009) 10:348-55. doi:10.1038/ni.1714

10. Ashkenazi A, Dixit VM. Death receptors: signaling and modulation. Science (1998) 281:1305-8. doi:10.1126/science.281.5381.1305

11. Chung JY, Park YC, Ye H, Wu H. All TRAFs are not created equal: common and distinct molecular mechanisms of TRAF-mediated signal transduction. $J$ Cell Sci (2002) 115:679-88.

12. Kirchner S, Holler E, Haffner S, Andreesen R, Eissner G. Effect of different tumor necrosis factor (TNF) reactive agents on reverse signaling of membrane integrated TNF in monocytes. Cytokine (2004) 28:67-74. doi:10.1016/j.cyto. 2004.06.008

13. Ringheanu M, Daum F, Markowitz J, Levine J, Katz S, Lin X, et al. Effects of infliximab on apoptosis and reverse signaling of monocytes from healthy individuals and patients with Crohn's disease. Inflamm Bowel Dis (2004) 10:801-10. doi:10.1097/00054725-200411000-00015

14. Bennett J, Basivireddy J, Kollar A, Biron KE, Reickmann P, Jefferies WA, et al. Blood-brain barrier disruption and enhanced vascular permeability in the multiple sclerosis model EAE. J Neuroimmunol (2010) 229:180-91. doi:10. 1016/j.jneuroim.2010.08.011

15. Alvarez JI, Cayrol R, Prat A. Disruption of central nervous system barriers in multiple sclerosis. Biochim Biophys Acta (2011) 1812:252-64. doi:10.1016/j. bbadis.2010.06.017

16. Huppert J, Closhen D, Croxford A, White R, Kulig P, Pietrowski E, et al. Cellular mechanisms of IL-17-induced blood-brain barrier disruption. FASEB $J$ (2010) 24:1023-34. doi:10.1096/fj.09-141978

17. Tam SJ, Richmond DL, Kaminker JS, Modrusan Z, Martin-McNulty B, Cao TC, et al. Death receptors DR6 and TROY regulate brain vascular development. Dev Cell (2012) 22:403-17. doi:10.1016/j.devcel.2011.11.018

18. Daneman R, Agalliu D, Zhou L, Kuhnert F, Kuo CJ, Barres BA. Wnt/betacatenin signaling is required for CNS, but not non-CNS, angiogenesis. Proc Natl Acad Sci U S A (2009) 106:641-6. doi:10.1073/pnas.0805165106

\section{Acknowledgments}

We thank Dr. Jyoti Rao and Dr. Deepa Subramanyam for critical reading, helpful discussion, and editing the manuscript. This work was supported by the Department of Biotechnology, Government of India (BT/RLF/Re-entry/41/2010, BT/03/IYBA/2010, and BT/PR4610/MED/30/720/2012 to GL). SS is Senior Research Fellow (SRF) of Council of Scientific and Industrial Research, Government of India.

19. Liebner S, Corada M, Bangsow T, Babbage J, Taddei A, Czupalla CJ, et al. Wnt/beta-catenin signaling controls development of the blood-brain barrier. $J$ Cell Biol (2008) 183:409-17. doi:10.1083/jcb.200806024

20. Hofman FM, Hinton DR, Johnson K, Merrill JE. Tumor necrosis factor identified in multiple sclerosis brain. J Exp Med (1989) 170:607-12. doi:10.1084/ jem.170.2.607

21. Kaltsonoudis E, Voulgari PV, Konitsiotis S, Drosos AA. Demyelination and other neurological adverse events after anti-TNF therapy. Autoimmun Rev (2014) 13:54-8. doi:10.1016/j.autrev.2013.09.002

22. Korner H, Lemckert FA, Chaudhri G, Etteldorf S, Sedgwick JD. Tumor necrosis factor blockade in actively induced experimental autoimmune encephalomyelitis prevents clinical disease despite activated $\mathrm{T}$ cell infiltration to the central nervous system. Eur J Immunol (1997) 27:1973-81. doi:10.1002/ eji. 1830270822

23. Sharief MK, Hentges R. Association between tumor necrosis factor-alpha and disease progression in patients with multiple sclerosis. N Engl J Med (1991) 325:467-72. doi:10.1056/NEJM199108153250704

24. Sharief MK, Hentges R, Ciardi M. Intrathecal immune response in patients with the post-polio syndrome. N Engl J Med (1991) 325:749-55. doi:10.1056/ NEJM199109123251101

25. Korner H, Riminton DS, Strickland DH, Lemckert FA, Pollard JD, Sedgwick JD. Critical points of tumor necrosis factor action in central nervous system autoimmune inflammation defined by gene targeting. J Exp Med (1997) 186:1585-90. doi:10.1084/jem.186.9.1585

26. Liu J, Marino MW, Wong G, Grail D, Dunn A, Bettadapura J, et al. TNF is a potent anti-inflammatory cytokine in autoimmune-mediated demyelination. Nat Med (1998) 4:78-83. doi:10.1038/nm0198-078

27. Probert L, Akassoglou K, Pasparakis M, Kontogeorgos G, Kollias G. Spontaneous inflammatory demyelinating disease in transgenic mice showing central nervous system-specific expression of tumor necrosis factor alpha. Proc Natl Acad Sci U S A (1995) 92:11294-8. doi:10.1073/pnas.92.24.11294

28. Ruddle NH, Bergman CM, McGrath KM, Lingenheld EG, Grunnet ML, Padula SJ, et al. An antibody to lymphotoxin and tumor necrosis factor prevents transfer of experimental allergic encephalomyelitis. J Exp Med (1990) 172:1193-200. doi:10.1084/jem.172.4.1193

29. Eugster HP, Frei K, Winkler F, Koedel U, Pfister W, Lassmann H, et al. Superantigen overcomes resistance of IL-6-deficient mice towards MOG-induced EAE by a TNFR1 controlled pathway. Eur J Immunol (2001) 31:2302-12. doi:10.1002/1521-4141(200108)31:8<2302::AID-IMMU2302>3.0.CO;2-\#

30. Eugster HP, Frei K, Bachmann R, Bluethmann H, Lassmann H, Fontana A. Severity of symptoms and demyelination in MOG-induced EAE depends on TNFR1. Eur J Immunol (1999) 29:626-32. doi:10.1002/(SICI) 1521-4141(199902)29:02<626::AID-IMMU626>3.0.CO;2-A

31. TNF neutralization in MS: results of a randomized, placebo-controlled multicenter study. The Lenercept Multiple Sclerosis Study Group and The University of British Columbia MS/MRI Analysis Group. Neurology (1999) 53:457-65. doi:10.1212/WNL.53.3.457

32. Kaltsonoudis E, Zikou AK, Voulgari PV, Konitsiotis S, Argyropoulou MI, Drosos AA. Neurological adverse events in patients receiving anti-TNF therapy: a prospective imaging and electrophysiological study. Arthritis Res Ther (2014) 16:R125. doi:10.1186/ar4582

33. van Boxel-Dezaire AH, Hoff SC, van Oosten BW, Verweij CL, Drager AM, Ader HJ, et al. Decreased interleukin-10 and increased interleukin-12p40 mRNA are associated with disease activity and characterize different disease stages in multiple sclerosis. Ann Neurol (1999) 45:695-703. doi:10.1002/ 1531-8249(199906)45:6<695::AID-ANA3>3.0.CO;2-R 
34. Magnano MD, Robinson WH, Genovese MC. Demyelination and inhibition of tumor necrosis factor (TNF). Clin Exp Rheumatol (2004) 22:S134-40.

35. Robinson WH, Genovese MC, Moreland LW. Demyelinating and neurologic events reported in association with tumor necrosis factor alpha antagonism: by what mechanisms could tumor necrosis factor alpha antagonists improve rheumatoid arthritis but exacerbate multiple sclerosis? Arthritis Rheum (2001) 44:1977-83. doi:10.1002/1529-0131(200109)44:9<1977:: AID-ART345>3.0.CO;2-6

36. Prinz JC. Autoimmune-like syndromes during TNF blockade: does infection have a role? Nat Rev (2011) 7:429-34. doi:10.1038/nrrheum.2011.35

37. Watanabe-Fukunaga R, Brannan CI, Copeland NG, Jenkins NA, Nagata S, Lymphoproliferation disorder in mice explained by defects in Fas antigen that mediates apoptosis. Nature (1992) 356:314-7. doi:10.1038/356314a0

38. Takahashi T, Tanaka M, Brannan CI, Jenkins NA, Copeland NG, Suda T, et al. Generalized lymphoproliferative disease in mice, caused by a point mutation in the Fas ligand. Cell (1994) 76:969-76. doi:10.1016/0092-8674(94)90375-1

39. Waldner H, Sobel RA, Howard E, Kuchroo VK. Fas- and FasL-deficient mice are resistant to induction of autoimmune encephalomyelitis. J Immunol (1997) 159:3100-3.

40. Suvannavejh GC, Dal Canto MC, Matis LA, Miller SD. Fas-mediated apoptosis in clinical remissions of relapsing experimental autoimmune encephalomyelitis. J Clin Invest (2000) 105:223-31. doi:10.1172/JCI8561

41. Okuda Y, Sakoda S, Fujimura H, Nagata S, Yanagihara T, Bernard CC. Intrathecal administration of neutralizing antibody against Fas ligand suppresses the progression of experimental autoimmune encephalomyelitis. Biochem Biophys Res Commun (2000) 275:164-8. doi:10.1006/bbrc.2000.3279

42. Zhu B, Luo L, Chen Y, Paty DW, Cynader MS. Intrathecal Fas ligand infusion strengthens immunoprivilege of central nervous system and suppresses experimental autoimmune encephalomyelitis. J Immunol (2002) 169:1561-9. doi:10.4049/jimmunol.169.3.1561

43. Sabelko-Downes KA, Cross AH, Russell JH. Dual role for Fas ligand in the initiation of and recovery from experimental allergic encephalomyelitis. J Exp Med (1999) 189:1195-205. doi:10.1084/jem.189.8.1195

44. Voskuhl RR, Peterson RS, Song B, Ao Y, Morales LB, Tiwari-Woodruff S, et al. Reactive astrocytes form scar-like perivascular barriers to leukocytes during adaptive immune inflammation of the CNS. J Neurosci (2009) 29:11511-22. doi:10.1523/JNEUROSCI.1514-09.2009

45. Wang X, Haroon F, Karray S, Martina D, Schluter D. Astrocytic Fas ligand expression is required to induce T-cell apoptosis and recovery from experimental autoimmune encephalomyelitis. Eur J Immunol (2013) 43:115-24. doi:10.1002/eji.201242679

46. Paul S, Singh AK, Shilpi, Lal G. Phenotypic and functional plasticity of gammadelta (yd) T cells in inflammation and tolerance. Int Rev Immunol (2014) 33:537-58. doi:10.3109/08830185.2013.863306

47. Ponomarev ED, Dittel BN. Gamma delta T cells regulate the extent and duration of inflammation in the central nervous system by a Fas ligand-dependent mechanism. J Immunol (2005) 174:4678-87. doi:10.4049/jimmunol.174.8. 4678

48. Schneider P, MacKay F, Steiner V, Hofmann K, Bodmer JL, Holler N, et al. BAFF, a novel ligand of the tumor necrosis factor family, stimulates B cell growth. J Exp Med (1999) 189:1747-56. doi:10.1084/jem.189.11.1747

49. Chu VT, Enghard P, Riemekasten G, Berek C. In vitro and in vivo activation induces BAFF and APRIL expression in B cells. J Immunol (2007) 179:5947-57. doi:10.4049/jimmunol.179.9.5947

50. Mackay F, Woodcock SA, Lawton P, Ambrose C, Baetscher M, Schneider P, et al. Mice transgenic for BAFF develop lymphocytic disorders along with autoimmune manifestations. J Exp Med (1999) 190:1697-710. doi:10.1084/ jem.190.11.1697

51. Stadanlick JE, Kaileh M, Karnell FG, Scholz JL, Miller JP, Quinn WJ III, et al. Tonic B cell antigen receptor signals supply an NF-kappaB substrate for prosurvival BLyS signaling. Nat Immunol (2008) 9:1379-87. doi:10.1038/ni. 1666

52. Meyer-Bahlburg A, Andrews SF, Yu KO, Porcelli SA, Rawlings DJ. Characterization of a late transitional B cell population highly sensitive to BAFFmediated homeostatic proliferation. J Exp Med (2008) 205:155-68. doi:10. 1084/jem. 20071088

53. Gross JA, Johnston J, Mudri S, Enselman R, Dillon SR, Madden K, et al. TACI and BCMA are receptors for a TNF homologue implicated in B-cell autoimmune disease. Nature (2000) 404:995-9. doi:10.1038/35010115
54. Rickert RC, Jellusova J, Miletic AV. Signaling by the tumor necrosis factor receptor superfamily in B-cell biology and disease. Immunol Rev (2011) 244:115-33. doi:10.1111/j.1600-065X.2011.01067.x

55. Schneider P, Takatsuka H, Wilson A, Mackay F, Tardivel A, Lens S, et al. Maturation of marginal zone and follicular B cells requires B cell activating factor of the tumor necrosis factor family and is independent of B cell maturation antigen. J Exp Med (2001) 194:1691-7. doi:10.1084/jem.194.11.1691

56. Marsters SA, Yan M, Pitti RM, Haas PE, Dixit VM, Ashkenazi A. Interaction of the TNF homologues BLyS and APRIL with the TNF receptor homologues BCMA and TACI. Curr Biol (2000) 10:785-8. doi:10.1016/S0960-9822(00) 00566-2

57. Kim SS, Richman DP, Zamvil SS, Agius MA. Accelerated central nervous system autoimmunity in BAFF-receptor-deficient mice. J Neurol Sci (2011) 306:9-15. doi:10.1016/j.jns.2011.04.008

58. Lee-Chang C, Lefranc D, Salleron J, Faveeuw C, Allet C, Vermersch P, et al. Susceptibility to experimental autoimmune encephalomyelitis is associated with altered B-cell subsets distribution and decreased serum BAFF levels. Immunol Lett (2011) 135:108-17. doi:10.1016/j.imlet.2010.10.006

59. Huntington ND, Tomioka R, Clavarino C, Chow AM, Linares D, Mana P, et al. A BAFF antagonist suppresses experimental autoimmune encephalomyelitis by targeting cell-mediated and humoral immune responses. Int Immunol (2006) 18:1473-85. doi:10.1093/intimm/dxl080

60. Zhou X, Xia Z, Lan Q, Wang J, Su W, Han YP, et al. BAFF promotes Th17 cells and aggravates experimental autoimmune encephalomyelitis. PLoS One (2011) 6:e23629. doi:10.1371/journal.pone.0023629

61. Jagessar SA, Heijmans N, Oh L, Bauer J, Blezer EL, Laman JD, et al. Antibodies against human BLyS and APRIL attenuate EAE development in marmoset monkeys. J Neuroimmune Pharmacol (2012) 7:557-70. doi:10.1007/ s11481-012-9384-x

62. Kala M, Miravalle A, Vollmer T. Recent insights into the mechanism of action of glatiramer acetate. J Neuroimmunol (2011) 235:9-17. doi:10.1016/ j.jneuroim.2011.01.009

63. Aharoni R, Vainshtein A, Stock A, Eilam R, From R, Shinder V, et al. Distinct pathological patterns in relapsing-remitting and chronic models of experimental autoimmune encephalomyelitis and the neuroprotective effect of glatiramer acetate. J Autoimmun (2011) 37:228-41. doi:10.1016/j.jaut.2011.06.003

64. Arnon R, Aharoni R. Neuroprotection and neurogeneration in MS and its animal model EAE effected by glatiramer acetate. J Neural Transm (2009) 116:1443-9. doi:10.1007/s00702-009-0272-3

65. Kala M, Rhodes SN, Piao WH, Shi FD, Campagnolo DI, Vollmer TL. B cells from glatiramer acetate-treated mice suppress experimental autoimmune encephalomyelitis. Exp Neurol (2010) 221:136-45. doi:10.1016/j.expneurol. 2009.10.015

66. Begum-Haque S, Sharma A, Christy M, Lentini T, Ochoa-Reparaz J, Fayed IF, et al. Increased expression of B cell-associated regulatory cytokines by glatiramer acetate in mice with experimental autoimmune encephalomyelitis. J Neuroimmunol (2010) 219:47-53. doi:10.1016/j.jneuroim.2009.11.016

67. Valzasina B, Guiducci C, Dislich H, Killeen N, Weinberg AD, Colombo MP. Triggering of OX40 (CD134) on CD4(+)CD25+ T cells blocks their inhibitory activity: a novel regulatory role for OX40 and its comparison with GITR. Blood (2005) 105:2845-51. doi:10.1182/blood-2004-07-2959

68. Croft M. Control of immunity by the TNFR-related molecule OX40 (CD134). Annu Rev Immunol (2010) 28:57-78. doi:10.1146/annurev-immunol-030409101243

69. Chen AI, McAdam AJ, Buhlmann JE, Scott S, Lupher ML Jr, Greenfield EA, et al. Ox40-ligand has a critical costimulatory role in dendritic cell:T cell interactions. Immunity (1999) 11:689-98. doi:10.1016/S1074-7613(00) 80143-0

70. Weinberg AD. OX40: targeted immunotherapy - implications for tempering autoimmunity and enhancing vaccines. Trends Immunol (2002) 23:102-9. doi:10.1016/S1471-4906(01)02127-5

71. Chitnis T, Najafian N, Abdallah KA, Dong V, Yagita H, Sayegh MH, et al. CD28-independent induction of experimental autoimmune encephalomyelitis. J Clin Invest (2001) 107:575-83. doi:10.1172/JCI11220

72. Ruby CE, Montler R, Zheng R, Shu S, Weinberg AD. IL-12 is required for antiOX40-mediated CD4 T cell survival. J Immunol (2008) 180:2140-8. doi:10. 4049/jimmunol.180.4.2140

73. Prell RA, Evans DE, Thalhofer C, Shi T, Funatake C, Weinberg AD. OX40mediated memory $\mathrm{T}$ cell generation is TNF receptor-associated factor 2 
dependent. J Immunol (2003) 171:5997-6005. doi:10.4049/jimmunol.171.11. 5997

74. So T, Croft M. Cutting edge: OX40 inhibits TGF-beta- and antigen-driven conversion of naive CD4 T cells into CD25+Foxp3+ T cells. J Immunol (2007) 179:1427-30. doi:10.4049/jimmunol.179.3.1427

75. Vu MD, Xiao X, Gao W, Degauque N, Chen M, Kroemer A, et al. OX40 costimulation turns off Foxp3+ Tregs. Blood (2007) 110:2501-10. doi:10.1182/ blood-2007-01-070748

76. Chen M, Xiao X, Demirci G, Li XC. OX40 controls islet allograft tolerance in CD154 deficient mice by regulating FOXP3+ Tregs. Transplantation (2008) 85:1659-62. doi:10.1097/TP.0b013e3181726987

77. Ito T, Wang YH, Duramad O, Hanabuchi S, Perng OA, Gilliet M, et al. OX40 ligand shuts down IL-10-producing regulatory T cells. Proc Natl Acad Sci U S A (2006) 103:13138-43. doi:10.1073/pnas.0603107103

78. Mahmud SA, Manlove LS, Schmitz HM, Xing Y, Wang Y, Owen DL, et al. Costimulation via the tumor-necrosis factor receptor superfamily couples TCR signal strength to the thymic differentiation of regulatory T cells. Nat Immunol (2014) 15:473-81. doi:10.1038/ni.2849

79. Xiao X, Kroemer A, Gao W, Ishii N, Demirci G, Li XC. OX40/OX40L costimulation affects induction of Foxp3+ regulatory $\mathrm{T}$ cells in part by expanding memory $\mathrm{T}$ cells in vivo. J Immunol (2008) 181:3193-201. doi:10.4049/ jimmunol.181.5.3193

80. Xiao X, Balasubramanian S, Liu W, Chu X, Wang H, Taparowsky EJ, et al. OX40 signaling favors the induction of $\mathrm{T}(\mathrm{H}) 9$ cells and airway inflammation. Nat Immunol (2012) 13:981-90. doi:10.1038/ni.2390

81. Weinberg AD, Bourdette DN, Sullivan TJ, Lemon M, Wallin JJ, Maziarz R, et al. Selective depletion of myelin-reactive T cells with the anti-OX-40 antibody ameliorates autoimmune encephalomyelitis. Nat Med (1996) 2:183-9. doi:10. 1038/nm0296-183

82. Weinberg AD, Wegmann KW, Funatake C, Whitham RH. Blocking OX40/OX-40 ligand interaction in vitro and in vivo leads to decreased $\mathrm{T}$ cell function and amelioration of experimental allergic encephalomyelitis. J Immunol (1999) 162:1818-26.

83. Kotani A, Hori T, Matsumura Y, Uchiyama T. Signaling of gp34 (OX40 ligand) induces vascular endothelial cells to produce a CC chemokine RANTES/CCL5. Immunol Lett (2002) 84:1-7. doi:10.1016/S0165-2478(02) 00082-2

84. Nohara C, Akiba H, Nakajima A, Inoue A, Koh CS, Ohshima H, et al. Amelioration of experimental autoimmune encephalomyelitis with anti-OX40 ligand monoclonal antibody: a critical role for OX40 ligand in migration, but not development, of pathogenic T cells. J Immunol (2001) 166:2108-15. doi:10.4049/jimmunol.166.3.2108

85. Yeo YA, Martinez Gomez JM, Croxford JL, Gasser S, Ling EA, Schwarz H. CD137 ligand activated microglia induces oligodendrocyte apoptosis via reactive oxygen species. J Neuroinflammation (2012) 9:173. doi:10.1186/ 1742-2094-9-173

86. Saoulli K, Lee SY, Cannons JL, Yeh WC, Santana A, Goldstein MD, et al. CD28independent, TRAF2-dependent costimulation of resting $\mathrm{T}$ cells by $4-1 \mathrm{BB}$ ligand. J Exp Med (1998) 187:1849-62. doi:10.1084/jem.187.11.1849

87. Sun Y, Lin X, Chen HM, Wu Q, Subudhi SK, Chen L, et al. Administration of agonistic anti-4-1BB monoclonal antibody leads to the amelioration of experimental autoimmune encephalomyelitis. J Immunol (2002) 168:1457-65. doi:10.4049/jimmunol.168.3.1457

88. Mittler RS, Bailey TS, Klussman K, Trailsmith MD, Hoffmann MK. Anti4-1BB monoclonal antibodies abrogate $\mathrm{T}$ cell-dependent humoral immune responses in vivo through the induction of helper T cell anergy. J Exp Med (1999) 190:1535-40. doi:10.1084/jem.190.10.1535

89. Martinez Gomez JM, Croxford JL, Yeo KP, Angeli V, Schwarz H, Gasser S. Development of experimental autoimmune encephalomyelitis critically depends on CD137 ligand signaling. J Neurosci (2012) 32:18246-52. doi:10. 1523/JNEUROSCI.2473-12.2012

90. Carrier Y, Whitters MJ, Miyashiro JS, LaBranche TP, Ramon HE, Benoit SE, et al. Enhanced GITR/GITRL interactions augment IL-27 expression and induce IL-10-producing Tr-1 like cells. Eur J Immunol (2012) 42:1393-404. doi:10.1002/eji.201142162

91. Coe D, Begom S, Addey C, White M, Dyson J, Chai JG. Depletion of regulatory $\mathrm{T}$ cells by anti-GITR $\mathrm{mAb}$ as a novel mechanism for cancer immunotherapy. Cancer Immunol Immunother (2010) 59:1367-77. doi:10. 1007/s00262-010-0866-5
92. Shimizu J, Yamazaki S, Takahashi T, Ishida Y, Sakaguchi S. Stimulation of $\mathrm{CD} 25(+) \mathrm{CD} 4(+)$ regulatory $\mathrm{T}$ cells through GITR breaks immunological selftolerance. Nat Immunol (2002) 3:135-42. doi:10.1038/ni759

93. Kanamaru F, Youngnak P, Hashiguchi M, Nishioka T, Takahashi T, Sakaguchi $\mathrm{S}$, et al. Costimulation via glucocorticoid-induced TNF receptor in both conventional and CD25+ regulatory CD4+ T cells. J Immunol (2004) 172:7306-14. doi:10.4049/jimmunol.172.12.7306

94. Ronchetti S, Nocentini G, Bianchini R, Krausz LT, Migliorati G, Riccardi C. Glucocorticoid-induced TNFR-related protein lowers the threshold of CD28 costimulation in CD8+ T cells. J Immunol (2007) 179:5916-26. doi:10.4049/ jimmunol.179.9.5916

95. Ronchetti S, Zollo O, Bruscoli S, Agostini M, Bianchini R, Nocentini G, et al. GITR, a member of the TNF receptor superfamily, is costimulatory to mouse T lymphocyte subpopulations. Eur J Immunol (2004) 34:613-22. doi:10.1002/ eji.200324804

96. Lal G, Nakayama Y, Sethi A, Singh AK, Burrell BE, Kulkarni N, et al. Interleukin-10 from marginal zone precursor B-cell subset is required for costimulatory blockade-induced transplantation tolerance. Transplantation (2015). doi:10.1097/TP.0000000000000718

97. Ray A, Mann MK, Basu S, Dittel BN. A case for regulatory B cells in controlling the severity of autoimmune-mediated inflammation in experimental autoimmune encephalomyelitis and multiple sclerosis. J Neuroimmunol (2011) 230:1-9. doi:10.1016/j.jneuroim.2010.10.037

98. Goetz M, Atreya R, Ghalibafian M, Galle PR, Neurath MF. Exacerbation of ulcerative colitis after rituximab salvage therapy. Inflamm Bowel Dis (2007) 13:1365-8. doi:10.1002/ibd.20215

99. van Olffen RW, Koning N, van Gisbergen KP, Wensveen FM, Hoek RM, Boon $\mathrm{L}$, et al. GITR triggering induces expansion of both effector and regulatory CD4+ T cells in vivo. J Immunol (2009) 182:7490-500. doi:10.4049/jimmunol. 0802751

100. Ray A, Basu S, Williams CB, Salzman NH, Dittel BN. A novel IL-10independent regulatory role for $\mathrm{B}$ cells in suppressing autoimmunity by main tenance of regulatory T cells via GITR ligand. J Immunol (2012) 188:3188-98. doi:10.4049/jimmunol.1103354

101. Hoffmann O, Zipp F, Weber JR. Tumour necrosis factor-related apoptosisinducing ligand (TRAIL) in central nervous system inflammation. J Mol Med (Berl) (2009) 87:753-63. doi:10.1007/s00109-009-0484-x

102. Cretney E, McQualter JL, Kayagaki N, Yagita H, Bernard CC, Grewal IS, et al. TNF-related apoptosis-inducing ligand (TRAIL)/Apo2L suppresses experimental autoimmune encephalomyelitis in mice. Immunol Cell Biol (2005) 83:511-9. doi:10.1111/j.1440-1711.2005.01358.x

103. Ikeda T, Hirata S, Fukushima S, Matsunaga Y, Ito T, Uchino M, et al. Dual effects of TRAIL in suppression of autoimmunity: the inhibition of Th1 cells and the promotion of regulatory T cells. J Immunol (2010) 185:5259-67. doi:10.4049/jimmunol.0902797

104. Hirata S, Matsuyoshi H, Fukuma D, Kurisaki A, Uemura Y, Nishimura Y, et al. Involvement of regulatory $\mathrm{T}$ cells in the experimental autoimmune encephalomyelitis-preventive effect of dendritic cells expressing myelin oligodendrocyte glycoprotein plus TRAIL. J Immunol (2007) 178:918-25. doi:10. 4049/jimmunol.178.2.918

105. Hirata S, Senju S, Matsuyoshi H, Fukuma D, Uemura Y, Nishimura Y. Prevention of experimental autoimmune encephalomyelitis by transfer of embryonic stem cell-derived dendritic cells expressing myelin oligodendrocyte glycoprotein peptide along with TRAIL or programmed death-1 ligand. J Immunol (2005) 174:1888-97. doi:10.4049/jimmunol.174.4.1888

106. Emery JG, McDonnell P, Burke MB, Deen KC, Lyn S, Silverman C, et al. Osteoprotegerin is a receptor for the cytotoxic ligand TRAIL. J Biol Chem (1998) 273:14363-7. doi:10.1074/jbc.273.23.14363

107. Cheng E, Armstrong CL, Galisteo R, Winkles JA. TWEAK/Fn14 axis-targeted therapeutics: moving basic science discoveries to the clinic. Front Immunol (2013) 4:473. doi:10.3389/fimmu.2013.00473

108. Potrovita I, Zhang W, Burkly L, Hahm K, Lincecum J, Wang MZ, et al. Tumor necrosis factor-like weak inducer of apoptosis-induced neurodegeneration. J Neurosci (2004) 24:8237-44. doi:10.1523/JNEUROSCI.1089-04. 2004

109. Desplat-Jego S, Varriale S, Creidy R, Terra R, Bernard D, Khrestchatisky $\mathrm{M}$, et al. TWEAK is expressed by glial cells, induces astrocyte proliferation and increases EAE severity. J Neuroimmunol (2002) 133:116-23. doi:10.1016/ S0165-5728(02)00368-5 
110. Mueller AM, Pedre X, Kleiter I, Hornberg M, Steinbrecher A, Giegerich G. Targeting fibroblast growth factor-inducible-14 signaling protects from chronic relapsing experimental autoimmune encephalomyelitis. J Neuroimmunol (2005) 159:55-65. doi:10.1016/j.jneuroim.2004.10.001

111. Sagar D, Lamontagne A, Foss CA, Khan ZK, Pomper MG, Jain P. Dendritic cell CNS recruitment correlates with disease severity in EAE via CCL2 chemotaxis at the blood-brain barrier through paracellular transmigration and ERK activation. J Neuroinflammation (2012) 9:245. doi:10.1186/1742-20949-245

112. Moreno M, Bannerman P, Ma J, Guo F, Miers L, Soulika AM, et al. Conditional ablation of astroglial CCL2 suppresses CNS accumulation of M1 macrophages and preserves axons in mice with MOG peptide EAE. J Neurosci (2014) 34:8175-85. doi:10.1523/JNEUROSCI.1137-14.2014

113. Zhang X, Winkles JA, Gongora MC, Polavarapu R, Michaelson JS, Hahm K, et al. TWEAK-Fn14 pathway inhibition protects the integrity of the neurovascular unit during cerebral ischemia. J Cereb Blood Flow Metab (2007) 27:534-44. doi:10.1038/sj.jcbfm.9600368

114. Polavarapu R, Gongora MC, Winkles JA, Yepes M. Tumor necrosis factorlike weak inducer of apoptosis increases the permeability of the neurovascular unit through nuclear factor-kappa B pathway activation. J Neurosci (2005) 25:10094-100. doi:10.1523/JNEUROSCI.3382-05.2005

115. Roos C, Wicovsky A, Muller N, Salzmann S, Rosenthal T, Kalthoff H, et al. Soluble and transmembrane TNF-like weak inducer of apoptosis differentially activate the classical and noncanonical NF-kappa B pathway. J Immunol (2010) 185:1593-605. doi:10.4049/jimmunol.0903555

116. Desplat-Jego S, Creidy R, Varriale S, Allaire N, Luo Y, Bernard D, et al. Anti-TWEAK monoclonal antibodies reduce immune cell infiltration in the central nervous system and severity of experimental autoimmune encephalomyelitis. Clin Immunol (2005) 117:15-23. doi:10.1016/j.clim.2005. 06.005

117. Perper SJ, Browning B, Burkly LC, Weng S, Gao C, Giza K, et al. TWEAK is a novel arthritogenic mediator. J Immunol (2006) 177:2610-20. doi:10.4049/ jimmunol.177.4.2610

118. Razmara M, Hilliard B, Ziarani AK, Murali R, Yellayi S, Ghazanfar M, et al. Fn14-TRAIL, a chimeric intercellular signal exchanger, attenuates experimental autoimmune encephalomyelitis. Am J Pathol (2009) 174:460-74. doi:10. 2353/ajpath.2009.080462

119. Prinz-Hadad H, Mizrachi T, Irony-Tur-Sinai M, Prigozhina TB, Aronin A, Brenner T, et al. Amelioration of autoimmune neuroinflammation by the fusion molecule Fn14.TRAIL. J Neuroinflammation (2013) 10:36. doi:10.1186/ 1742-2094-10-36

120. Nolte MA, van Olffen RW, van Gisbergen KP, van Lier RA. Timing and tuning of CD27-CD70 interactions: the impact of signal strength in setting the balance between adaptive responses and immunopathology. Immunol Rev (2009) 229:216-31. doi:10.1111/j.1600-065X.2009.00774.x

121. Nakajima A, Oshima H, Nohara C, Morimoto S, Yoshino S, Kobata T, et al. Involvement of CD70-CD27 interactions in the induction of experimental autoimmune encephalomyelitis. J Neuroimmunol (2000) 109:188-96. doi:10. 1016/S0165-5728(00)00324-6

122. Ribot JC, deBarros A, Pang DJ, Neves JF, Peperzak V, Roberts SJ, et al. CD27 is a thymic determinant of the balance between interferon-gammaand interleukin 17-producing gammadelta T cell subsets. Nat Immunol (2009) 10:427-36. doi:10.1038/ni.1717

123. Paul S, Shilpi, Lal G. Role of gamma-delta (gammadelta) T cells in autoimmunity. J Leukoc Biol (2015) 97:259-71. doi:10.1189/jlb.3RU0914-443R

124. Coquet JM, Middendorp S, van der Horst G, Kind J, Veraar EA, Xiao Y, et al. The CD27 and CD70 costimulatory pathway inhibits effector function of T helper 17 cells and attenuates associated autoimmunity. Immunity (2013) 38:53-65. doi:10.1016/j.immuni.2012.09.009

125. Wang X, Dong C. The CD70-CD27 axis, a new brake in the T helper 17 cell response. Immunity (2013) 38:1-3. doi:10.1016/j.immuni.2013.01.005

126. Francosalinas G, Cantaert T, Nolte MA, Tak PP, van Lier RA, Baeten DL. Enhanced costimulation by $\mathrm{CD} 70+\mathrm{B}$ cells aggravates experimental autoimmune encephalomyelitis in autoimmune mice. J Neuroimmunol (2013) 255:8-17. doi:10.1016/j.jneuroim.2012.10.010
127. Tesselaar K, Arens R, van Schijndel GM, Baars PA, van der Valk MA, Borst $\mathrm{J}$, et al. Lethal $\mathrm{T}$ cell immunodeficiency induced by chronic costimulation via CD27-CD70 interactions. Nat Immunol (2003) 4:49-54. doi:10.1038/ni869

128. Gommerman JL, Giza K, Perper S, Sizing I, Ngam-Ek A, Nickerson-Nutter $\mathrm{C}$, et al. A role for surface lymphotoxin in experimental autoimmune encephalomyelitis independent of LIGHT. J Clin Invest (2003) 112:755-67. doi:10.1172/JCI18648

129. De Togni P, Goellner J, Ruddle NH, Streeter PR, Fick A, Mariathasan S, et al. Abnormal development of peripheral lymphoid organs in mice deficient in lymphotoxin. Science (1994) 264:703-7. doi:10.1126/science.8171322

130. Suen WE, Bergman CM, Hjelmstrom P, Ruddle NH. A critical role for lymphotoxin in experimental allergic encephalomyelitis. J Exp Med (1997) 186:1233-40. doi:10.1084/jem.186.8.1233

131. Mana P, Linares D, Silva DG, Fordham S, Scheu S, Pfeffer K, et al. LIGHT (TNFSF14/CD258) is a decisive factor for recovery from experimental autoimmune encephalomyelitis. J Immunol (2013) 191:154-63. doi:10.4049/ jimmunol.1203016

132. Gerritse K, Laman JD, Noelle RJ, Aruffo A, Ledbetter JA, Boersma WJ, et al. CD40-CD40 ligand interactions in experimental allergic encephalomyelitis and multiple sclerosis. Proc Natl Acad Sci U S A (1996) 93:2499-504. doi:10. 1073/pnas.93.6.2499

133. Ponomarev ED, Shriver LP, Dittel BN. CD40 expression by microglial cells is required for their completion of a two-step activation process during central nervous system autoimmune inflammation. J Immunol (2006) 176:1402-10. doi:10.4049/jimmunol.176.3.1402

134. Kim DY, Hong GU, Ro JY. Signal pathways in astrocytes activated by cross-talk between of astrocytes and mast cells through CD40-CD40L. JNeuroinflammation (2011) 8:25. doi:10.1186/1742-2094-8-25

135. Girvin AM, Dal Canto MC, Miller SD. CD40/CD40L interaction is essential for the induction of EAE in the absence of CD28-mediated co-stimulation. $J$ Autoimmun (2002) 18:83-94. doi:10.1006/jaut.2001.0573

136. Grewal IS, Foellmer HG, Grewal KD, Xu J, Hardardottir F, Baron JL, et al. Requirement for CD40 ligand in costimulation induction, $\mathrm{T}$ cell activation, and experimental allergic encephalomyelitis. Science (1996) 273:1864-7. doi:10.1126/science.273.5283.1864

137. Howard LM, Dal Canto MC, Miller SD. Transient anti-CD154-mediated immunotherapy of ongoing relapsing experimental autoimmune encephalomyelitis induces long-term inhibition of disease relapses. $J$ Neuroimmunol (2002) 129:58-65. doi:10.1016/S0165-5728(02)00175-3

138. Ndhlovu LC, Ishii N, Murata K, Sato T, Sugamura K. Critical involvement of OX40 ligand signals in the $\mathrm{T}$ cell priming events during experimental autoimmune encephalomyelitis. J Immunol (2001) 167:2991-9. doi:10.4049/ jimmunol.167.5.2991

139. Becher B, Durell BG, Miga AV, Hickey WF, Noelle RJ. The clinical course of experimental autoimmune encephalomyelitis and inflammation is controlled by the expression of CD40 within the central nervous system. J Exp Med (2001) 193:967-74. doi:10.1084/jem.193.8.967

140. Iezzi G, Sonderegger I, Ampenberger F, Schmitz N, Marsland BJ, Kopf M. CD40-CD40L cross-talk integrates strong antigenic signals and microbial stimuli to induce development of IL-17-producing CD4+ T cells. Proc Natl Acad Sci U S A (2009) 106:876-81. doi:10.1073/pnas.0810769106

141. Wang Y, Subudhi SK, Anders RA, Lo J, Sun Y, Blink S, et al. The role of herpesvirus entry mediator as a negative regulator of $\mathrm{T}$ cell-mediated responses. J Clin Invest (2005) 115:711-7. doi:10.1172/JCI22982

Conflict of Interest Statement: The authors declare that the research was conducted in the absence of any commercial or financial relationships that could be construed as a potential conflict of interest.

Copyright (C) 2015 Sonar and Lal. This is an open-access article distributed under the terms of the Creative Commons Attribution License (CC BY). The use, distribution or reproduction in other forums is permitted, provided the original author(s) or licensor are credited and that the original publication in this journal is cited, in accordance with accepted academic practice. No use, distribution or reproduction is permitted which does not comply with these terms. 